Retraction

\title{
Retraction: Hsia, T.-C., et al. Advanced Glycation End-Products Enhance Lung Cancer Cell Invasion and Migration. Int. J. Mol. Sci. 2016, 17, 1289, doi:10.3390/ijms17081289
}

\author{
International Journal of Molecular Sciences Editorial Office
}

MDPI AG, St. Alban-Anlage 66, 4052 Basel, Switzerland

Received: 26 July 2017; Accepted: 27 July 2017; Published: 28 July 2017

In article [1], several Western blot bands in Figures 1-4 have been questioned due to similarity. The authors' usual protocol is to photograph the final Western blot bands save them as TIF files. Unfortunately, the authors did not keep TIF files for all of the questioned bands. Thus, by mutual agreement between the authors and the journal, the article will be retracted. The authors apologize for any inconvenience caused, and intend to carry out the reported experiments again and submit it as a new article.

The article will be marked as retracted. The International Journal of Molecular Sciences is a member of COPE and takes research integrity, including the correct reporting of figures, very seriously.

\section{Reference}

1. Hsia, T.-C.; Yin, M.-C.; Mong, M.-C. Advanced Glycation End-Products Enhance Lung Cancer Cell Invasion and Migration. Int. J. Mol. Sci. 2016, 17, 1289. [CrossRef] [PubMed]

(C) 2017 by the author. Licensee MDPI, Basel, Switzerland. This article is an open access article distributed under the terms and conditions of the Creative Commons Attribution (CC BY) license (http:/ / creativecommons.org/licenses/by/4.0/). 